\title{
Considerações sobre o direito à moradia e a usucapião em áreas ambientalmente protegidas
}

\author{
Vladimir Passos Freitas ${ }^{1}$ \\ Amanda Amorim Maciel $^{2}$ \\ Mariana Almeida Passos de Freitas ${ }^{3}$
}

\begin{abstract}
Resumo
A diversidade de recursos naturais do Brasil motivou o legislador a prever diversas espécies de proteção, destacando-se as unidades de conservação e as áreas de preservação permanente. Por sua vez, o crescimento da população, a migração campo cidade e as dificuldades de moradia resultam, por vezes, na ocupação das áreas protegidas. O direito à moradia e ao gozo de um ambiente ecologicamente equilibrado são assegurados aos brasileiros pela Constituição Federal. O presente artigo tem por objetivo analisar a possibilidade de reconhecer-se a usucapião nas áreas ambientais protegidas e as dificuldades para avaliar qual direito deve prevalecer nos casos de conflito entre ambos.

Palavras-chave: Unidade de conservação. Área de preservação permanente. Usucapião. Moradia e meio ambiente.

\section{Considerations on the right to housing and usucaption in environmentally protected areas}

\begin{abstract}
The diversity of natural resources in Brazil was a reason for the legislator to provide for different kinds of protection, especially the conservation units and areas of permanent preservation. In turn, the population growth, the migration from rural zones to cities and the housing difficulties lead, sometimes, to the occupation of protected areas. The right to housing and to the enjoyment of an ecologically balanced environment are provided to the Brazilian people by the Federal Constitution. This article aims to analyze the possibility of recognizing the usucaption in protected environmental areas and the difficulties to assess which right must prevail in cases of conflict between them.
\end{abstract}

Keywords: Conservation unit. Permanent preservation area. Usucaption. Housing and environment.

\section{Introdução}

A usucapião, importante e antigo instituto existente em nosso ordenamento jurídico, garante a aquisição de propriedade em decorrência do exercício da posse de forma prolongada ou, excepcionalmente, por períodos menores em áreas urbanas. A usucapião baseia-se na necessidade do reconhecimento de domínio ao possuidor e atende, atualmente, ao mandamento constitucional que vincula a propriedade à sua função social.

Por sua vez, o meio ambiente ecologicamente equilibrado foi alçado a direito fundamental na Constituição Federal de 1988, devendo ser garantido e protegido pelo Poder Público e pela coletividade.

Entre as diversas formas de proteção dos bens ambientais no Brasil, encontram-se as unidades de conservação e as áreas de preservação permanente. Todavia, por vezes, existem pessoas que vivem no interior destes locais especialmente protegidos. Tal fato, pouco pesquisado nos estudos acadêmicos, merece atenção especial. É preciso discutir-se a existência ou não da possibilidade de reconhecer-se a usucapião nestas áreas protegidas. Neste desiderato, far-se-á, inicialmente, um bre- 
ve estudo acerca da usucapião, suas espécies, previsão jurídica e importância. Ainda nesta temática, o estudo abrangerá o procedimento da usucapião no novo Código de Processo Civil.

$\mathrm{Na}$ sequência, será abordada a questão da disponibilidade dos bens ambientais, qual tratamento jurídico eles recebem no Brasil. Em seguida, será feito o estudo das unidades de conservação propriamente ditas, os grupos em que se dividem, suas espécies e relevância da proteção ambiental, bem como os limites e circunstâncias da usucapião de imóveis em unidades de conservação, isto é, se existe essa possibilidade e quais os requisitos. Finalmente, a mesma análise, porém voltada para as áreas de preservação permanente no Código Florestal de 2012.

\section{A usucapião}

Instituto antigo, a usucapião ganhou real importância a partir do Direito Romano, com a "Lei das XII Tábuas", 455 antes de Cristo. Sílvio de Salvo Venosa (2003, p. 190) ensina que "denomina-se usucapião o modo de aquisição de propriedade mediante a posse suficientemente prolongada sob determinadas condições". As condições a que se refere o autor são os requisitos previstos no ordenamento jurídico.

A usucapião fundamenta-se, eminentemente, na função social da propriedade, elevada a princípio em nossa atual Constituição Federal, no art. 5 XXIII. Conforme ensina Orlando Gomes (2010, p. 258):

O fundamento da usucapião está assentado, assim, no princípio da utilidade social, na conveniência de se dar segurança e estabilidade à propriedade, bem como de se consolidar as aquisições e facilitar a prova do domínio. Tal instituto, segundo consagrada doutrina, repousa na paz social e estabelece a firmeza da propriedade, libertando-a das reivindicações inesperadas, corta pela raiz um grande número de pleitos, planta a paz e a tranquilidade na vida social: tem aprovação dos séculos e o consenso unânime dos povos antigos e modernos.

No ordenamento jurídico brasileiro estão previstas inúmeras espécies de usucapião, de importante menção no presente trabalho, para que seja possível compreendermos as análises subsequentes.

A primeira delas é a usucapião ordinária, prevista no art. 1.242 do Código Civil, tratando-se de aquisição do domínio por tempo mínimo determinado, sem interrupção devidamente comprovada, sendo necessária a presença da boa-fé:

Art. 1.242. Adquire também a propriedade do imóvel aquele que, contínua e incontestadamente, com justo título e boa-fé, o possuir por dez anos.

Parágrafo único. Será de cinco anos o prazo previsto neste artigo se o imóvel houver sido adquirido, onerosamente, com base no registro constante do respectivo cartório, cancelada posteriormente, desde que os possuidores nele tiverem estabelecido a sua moradia, ou realizado investimentos de interesse social e econômico.

Por sua vez, a usucapião extraordinária é a modalidade mais longa de usucapião, sendo de quinze anos, com possibilidade da redução para dez anos:

Art. 1.238. Aquele que, por quinze anos, sem interrupção, nem oposição, possuir como seu um imóvel, adquire-lhe a propriedade, independentemente de título e boa-fé; podendo 
requerer ao juiz que assim o declare por sentença, a qual servirá de título para o registro no Cartório de Registro de Imóveis.

Parágrafo único. O prazo estabelecido neste artigo reduzir-se-á a dez anos se o possuidor houver estabelecido no imóvel a sua moradia habitual, ou nele realizado obras ou serviços de caráter produtivo.

Menos rigoroso e com nítido objetivo de pacificação social é a usucapião urbana, constante do art. 183 da Constituição Federal, art. 1.240 do Código Civil e art. $9^{\circ}$ do Estatuto da Cidade, que possuem a mesma redação:
Art. 183. Aquele que possuir como sua área urbana de até duzentos e cinqüenta metros quadrados, por cinco anos, ininterruptamente e sem oposição, utilizando-a para sua moradia ou de sua família, adquirir-lhe-á o domínio, desde que não seja proprietário de outro imóvel urbano ou rural. $\S 1^{\circ} \mathrm{O}$ título de domínio e a concessão de uso serão conferidos ao homem ou à mulher, ou
a ambos, independentemente do estado civil.
$\S 2^{\circ}$ Esse direito não será reconhecido ao mesmo possuidor mais de uma vez.

Outra modalidade é a usucapião especial rural, contemplada também pela Constituição Federal em seu art. 191, pelo Código Civil, art. 1.239, e pela Lei no 6.969/1981, que regulou inteiramente a matéria, antes disciplinada pelo chamado Estatuto da Terra:

\footnotetext{
Art. 191. Aquele que, não sendo proprietário de imóvel rural ou urbano, possua como seu, por cinco anos ininterruptos, sem oposição, área de terra, em zona rural, não superior a cinquenta hectares, tornando-a produtiva por seu trabalho ou de sua família, tendo nela sua moradia, adquirir-lhe-á a propriedade.

Parágrafo único. Os imóveis públicos não serão adquiridos por usucapião.
}

Finalmente, há que se mencionar a Lei $\mathrm{n}^{\circ} 11.977$, de 2009, que trata do programa de habitações populares (Minha casa, minha vida) e da regularização fundiária de assentamentos localizados em áreas urbanas. Referida lei não cuida da usucapião, todavia prevê no art. 46 a regularização fundiária, que consiste no conjunto de medidas jurídicas, urbanísticas, ambientais e sociais que visam à regularização de assentamentos irregulares e à titulação de seus ocupantes. Cabe ao município esta regularização, que muito se assemelha à usucapião, sendo que no art. 54, § $1^{\circ}$, a lei dá-lhe poderes para admitir a regularização fundiária de interesse social em Áreas de Preservação Permanente, ocupadas até 31 de dezembro de 2007 e inseridas em área urbana consolidada. O deferimento do pedido resulta na legitimação da posse e esta poderá ser levada, após 5 (cinco) anos, ao oficial do Cartório de Registro de Imóveis, para fins de conversão em título de propriedade. Por derradeiro, registre-se que o $\S 3^{\circ}$ deste artigo permite que, no caso de imóvel em área urbana, com mais de 250 $\mathrm{m}^{2}$, o prazo para conversão em propriedade será o da legislação sobre usucapião.

Estas são as espécies de usucapião existentes em nosso ordenamento jurídico, sendo possível verificar que o bem protegido é o direito à moradia, direito social, com previsão no art. $6^{\circ}$ da Constituição Federal, cuja estabilidade se pretende consolidar com o reconhecimento da propriedade. Segundo Uadi Lammêgo Bulos (2009, p. 422),

percebe-se que o direito à moradia é um direito essencial, já há muito tempo fazendo parte do texto constitucional, agora robustecido com sua expressa menção no elenco do artigo $6^{\text {o; }}$ proporcionando, no mínimo, a facilitação da exigência de sua concretização. Os direitos sociais também funcionam para garantir que o patrimônio humano seja preservado. 


\section{A usucapião no novo Código de Processo Civil}

Vistos brevemente o conceito, a importância e as espécies de usucapião, passa-se ao estudo das mudanças ocorridas em seu procedimento, após a promulgação do novo Código de Processo Civil.

Diferentemente do anterior, no atual Código de Processo Civil não houve a previsão de procedimento especial quanto à usucapião. Assim, esta ação passa a se inserir dentro daquelas de procedimento comum. No entanto, há algumas menções ao instituto nos artigos 246 e 259, no seguinte sentido:

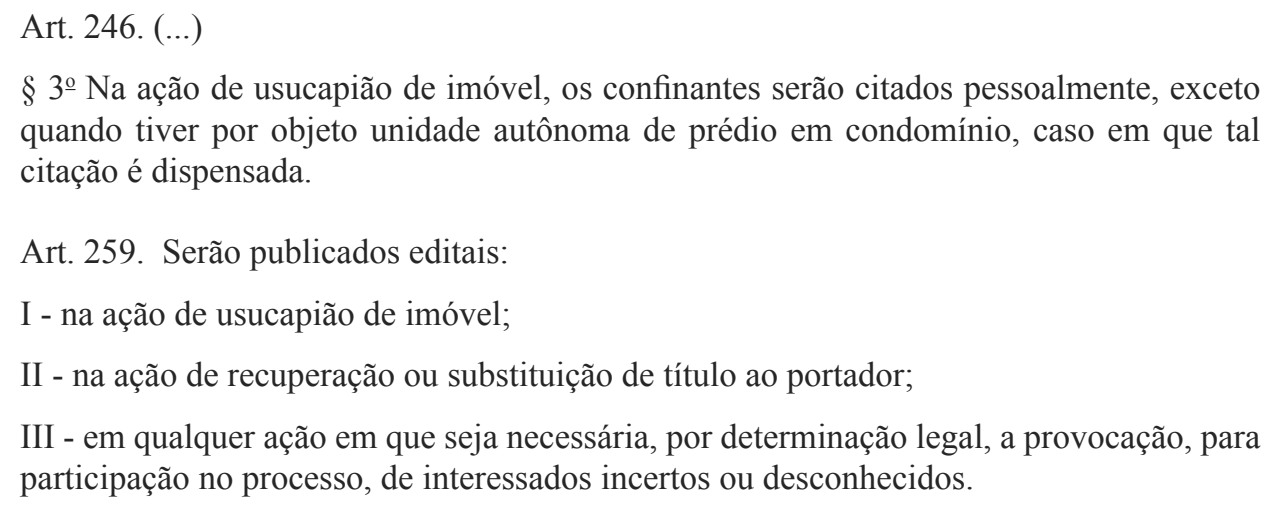

No que diz respeito especificamente à usucapião extrajudicial com base no artigo 1.071 no novo Código, a Lei de Registros Públicos (Lei 6.015/1973) passa a ser acrescida do artigo 216-A, que regula o procedimento da usucapião a ser requerido perante o oficial de registro de imóveis. ${ }^{4}$ Esta prática se insere no fenômeno da desjudicialização ou extrajudicialização do Direito, consubstanciado no deslocamento de competências do Poder Judiciário para órgãos extrajudiciais, principalmente as serventias notariais e registrais.

Do $\S 1^{\circ}$ ao $10^{\circ}$ do citado art. 216-A estão as regras processuais para que possa o pedido tramitar fora do Juízo. E aí cabe registrar que, nada obstante o fim da previsão de um procedimento específico, o trâmite da ação de usucapião continua o mesmo. Ainda deve haver a citação da pessoa em cujo nome o imóvel está registrado, dos vizinhos confinantes e dos demais interessados, estes últimos por edital. Cesar Fiuza é claro ao afirmar que:

Embora o novo Código de Processo Civil não mencione estes últimos, entende-se ser necessário citá-los, tendo em vista o procedimento administrativo da Lei de Registros Públicos. Ora, se no procedimento notarial é necessário dar ciência a esses terceiros interessados, porque seria dispensável sua citação no processo judicial, como, aliás, o era no Código de Processo de 1973? De fato, segundo a nova redação da Lei 6.015/73, o oficial de registro de imóveis também promoverá a publicação de edital em jornal de grande circulação, onde houver, para a ciência de terceiros eventualmente interessados, que poderão se manifestar em 15 dias.

Reforçando o argumento, o próprio Código de Processo de 2015, no inciso I do artigo 259, dispõe que serão publicados editais na ação de usucapião. Ora, editais referentes a quê, senão à citação dos demais interessados? A primeira dúvida, portanto, a nosso ver, deve ser solucionada nesse sentido, ou seja, eventuais terceiros interessados deverão ser citados por edital, como no procedimento notarial e no do antigo Código de Processo Civil (FIUZA, 2015). 
O mesmo raciocínio deve ser aplicado quanto à intimação de representantes do Município, Estado, Distrito Federal e União, sobre o interesse na causa.

Tecidas estas considerações acerca da usucapião, para bem visualizá-la, passa-se neste momento à questão ambiental propriamente dita, a fim de, posteriormente, realizar a análise sobre a possibilidade de usucapião em áreas ambientalmente protegidas.

\section{A controvertida disponibilidade dos bens ambientais}

A disponibilidade dos bens ambientais obriga a uma análise preliminar de sua natureza jurídica. Ignorados pelas Constituições brasileiras até 1988, nesta eles foram considerados, no art. 225, caput, como "bens de uso comum do povo". Esta denominação, típica do Direito Civil, é herança do Direito Romano, que os tratava por res comunes omnium, ou seja, os que não poderiam ser objeto de apropriação individual.

Ocorre que a classificação constitucional encontra sérias dificuldades para que seja assim reconhecida. Primeiro, porque é a própria Constituição que atribui a alguns bens ambientais a propriedade por parte de pessoas jurídicas. Por exemplo, o art. 26, I, afirma pertencerem aos estados as águas subterrâneas que se encontram em seu território. Ora, diante desta regra especial, como considerar referidas águas bens de uso comum do povo, com base na regra geral do art. 225 ?

Mas, ainda que os bens ambientais sejam considerados de propriedade pública ou privada, ou mesmo de uso comum do povo, isto não significa que deles se possa fazer o uso que quiser.

O fato de a União ser considerada pela Constituição, no art. 20, III, proprietária dos rios que banhem mais de um estado, não lhe dá o poder de, neles, realizar qualquer obra de vulto sem submeter-se aos regramentos ambientais, tal qual fosse um particular. Imagine-se um serviço de transporte aquaviário no rio Paraná, que é federal, por separar os Estados de São Paulo e Mato Grosso do Sul: ainda que implantado pela União, deveria sujeitar-se a estudo de impacto ambiental.

Curiosamente, se o rio Paraná fosse simplesmente bem de uso comum do povo, a solução seria a mesma, pois, como alerta Sílvio de Sálvio Venosa (2003, p. 340), "sobre esses bens de uso comum, a administração tem a guarda, direção e fiscalização". Portanto, o estudo de impacto ambiental seria, da mesma forma, exigido.

José Afonso da Silva (2011, p. 86) adota uma terceira posição:

A Constituição, no art. 225, declara que todos têm direito ao meio ambiente ecologicamente equilibrado. Veja-se que o objeto do direito de todos não é o meio ambiente em si, não é qualquer meio ambiente. O que é objeto do direito é o meio ambiente qualificado. O direito que todos temos é à qualidade satisfatória, ao equilíbrio ecológico do meio ambiente. Essa qualidade é que se converteu em um bem jurídico. A isso é que a Constituição define como bem de uso comum do povo, e essencial à sadia qualidade de vida. Teremos que fazer especificações depois, mas, de um modo geral, pode-se dizer que tudo isso significa que esses atributos do meio ambiente não podem ser de apropriação privada mesmo quando seus elementos constitutivos pertençam a particulares. Significa que o proprietário, seja pessoa pública ou particular, não pode dispor da qualidade do meio ambiente a seu belprazer, porque ela não integra a sua disponibilidade. Veremos, no entanto, que há elementos físicos do meio ambiente que também não são suscetíveis de apropriação privada, como o ar, a água, que são, já por si, bens de uso comum do povo. Por isso, como a qualidade ambiental, não são bens públicos nem particulares. São bens de interesse público, dotados de um regime jurídico especial, enquanto essenciais à sadia qualidade de vida e vinculados, assim, a um fim de interesse coletivo. 
Assim, considere-se o bem ambiental como de propriedade de quem a Constituição ou a lei indicar, como bem de uso comum do povo ou como bem de interesse público dotado de regime jurídico especial, não sendo, portanto, nem público nem particular, o tratamento que a ele se dará será o mesmo. É dizer, em qualquer das hipóteses as normas de proteção ambiental incidirão sobre o bem ambiental.

Contudo, tal conclusão não significa que nenhuma relação privada possa ser efetivada em espaços ambientalmente protegidos. Acerca deste tema, ensina Patryck de Araújo Ayala (2007, p. 268) que "a imposição de condicionamentos relacionados à função social dos espaços e dos bens de interesse ambiental não significa que não seja possível o estabelecimento de relações privadas, seja sobre os espaços, seja sobre seus elementos".

E prossegue, reafirmando a relevância da preservação ambiental, que deve preponderar: “quando a apropriação privada é admitida (...), há finalidades específicas e previamente definidas que devem ser realizadas pelo proprietário, como condição para a permanência dos direitos que detém sobre o espaço, sendo que todas elas devem expressar objetivos de sustentabilidade" (AYALA, 2007, p. 275).

O conflito entre os bens ambientais de natureza pública e a exploração econômica foram analisados por Vladimir Passos de Freitas (2015, p. 217-234), em artigo sobre a exploração de cachoeiras por particulares. Destarte, é possível concluir neste tópico que nada obstante a discussão sobre a natureza dos bens ambientais, é possível a apropriação privada de certos recursos naturais em áreas ambientalmente protegidas, desde que legalmente permitida.

\title{
Unidades de conservação no Brasil
}

Uma das formas mais importantes de proteção dos bens ambientais é a criação de unidades de conservação. A Constituição Federal prevê em seu art. 225, § 1º, III, que o Poder Público poderá criar "espaços territoriais e seus componentes a serem especialmente protegidos, sendo a alteração e a supressão permitidas somente através de lei”. Isto significa que a União, Estados e Municípios podem criar áreas protegidas por ato do Poder Executivo, consubstanciado em Decreto. Mas, para extingui-las, será preciso lei, ou seja, decisão do Poder Legislativo evidentemente mais complexa e sujeita à discussão pela sociedade.

José Afonso da Silva (2004 p. 230) define estes espaços como:

\begin{abstract}
áreas geográficas públicas ou privadas (porção do território nacional) dotadas de atributos que requeiram sua sujeição, pela lei, a um regime jurídico de interesse público que implique sua relativa imodificabilidade e sua utilização sustentada, tendo em vista a preservação e proteção da integridade de amostras de toda a diversidade de ecossistemas, a proteção ao processo evolutivo das espécies, a preservação e proteção dos recursos naturais.
\end{abstract}

Assim, as unidades de conservação são um tipo especial de área protegida, na verdade espaços territoriais (incluindo seus recursos ambientais e as águas jurisdicionais) com características naturais relevantes, legalmente instituídos pelo Poder Público, com objetivos de conservação e de limites definidos, sob regime especial de administração, aos quais se aplicam garantias adequadas de proteção, a depender da espécie. 
A fim de regulamentar a matéria, foi editada a Lei 9.985, de 18 de julho de 2000, que criou o Sistema Nacional de Unidades de Conservação da Natureza, a chamada Lei do SNUC, definindo o local como áreas de "características naturais relevantes, legalmente instituído pelo Poder Público, com objetivos de conservação e limites definidos, sob regime especial de administração, ao qual se aplicam garantias adequadas de proteção" (art. 2º, I, da Lei do SNUC).

A promulgação desta lei foi de extrema relevância, sendo importante mencionar a análise feita por José Eduardo Ramos Rodrigues (2005, p. 55) acerca do tema:

\begin{abstract}
Antes de partir para a análise técnico-jurídica do tema, é preciso primordialmente ressaltar que o SNUC foi criado por lei na forma de um sistema. Como vimos acima, anteriormente a legislação sobre Unidades de Conservação nada mais era que uma série fragmentada de dispositivos legais dispersos, cuja compreensão científica fazia-se quase impossível. Hoje temos um sistema, um todo formado de disposições legais articuladas e correlacionadas entre si. E é desta forma que ele deve ser estudado.
\end{abstract}

Esta lei dividiu as unidades de conservação em dois grandes grupos, que são: as unidades de proteção integral e as de uso sustentável.

As Unidades de Conservação de Proteção Integral têm por “objetivo básico preservar a natureza, sendo admitido apenas o uso indireto dos seus recursos naturais, com exceção dos casos previstos nesta Lei" $\left(\operatorname{art.} 7^{\circ}, \S 1^{\circ}\right)$. Em regra, este uso indireto refere-se à pesquisa científica e à educação ambiental. As espécies de unidades de conservação de proteção integral constituem-se em: Estações Ecológicas, Reservas Biológicas, Parques, Monumentos Naturais e Refúgio da Vida Silvestre.

É essencial verificar o que prevê a lei acerca de cada espécie de unidade de conservação integral, no que diz respeito ao seu uso e proteção do meio ambiente, a fim de avaliar a possibilidade ou não de reconhecer-se a usucapião. Vejamos:

Art. 9을 A Estação Ecológica tem como objetivo a preservação da natureza e a realização de pesquisas científicas.

Art. 10. A Reserva Biológica tem como objetivo a preservação integral da biota e demais atributos naturais existentes em seus limites, sem interferência humana direta ou modificações ambientais, excetuando-se as medidas de recuperação de seus ecossistemas alterados e as ações de manejo necessárias para recuperar e preservar o equilíbrio natural, a diversidade biológica e os processos ecológicos naturais.

Art. 11. O Parque Nacional tem como objetivo básico a preservação de ecossistemas naturais de grande relevância ecológica e beleza cênica, possibilitando a realização de pesquisas científicas e o desenvolvimento de atividades de educação e interpretação ambiental, de recreação em contato com a natureza e de turismo ecológico.

Art. 12. O Monumento Natural tem como objetivo básico preservar sítios naturais raros, singulares ou de grande beleza cênica.

Art. 13. O Refúgio de Vida Silvestre tem como objetivo proteger ambientes naturais onde se asseguram condições para a existência ou reprodução de espécies ou comunidades da flora local e da fauna residente ou migratória.

Já as Unidades de Conservação de Uso Sustentável têm o objetivo de "compatibilizar a conservação da natureza com o uso sustentável de parcela dos seus recursos naturais" (art. $7^{\circ}, \S 2^{\circ}$, da Lei do SNUC). São elas: 
Art. 15. A Área de Proteção Ambiental é uma área em geral extensa, com um certo grau de ocupação humana, dotada de atributos abióticos, bióticos, estéticos ou culturais especialmente importantes para a qualidade de vida e o bem-estar das populações humanas, e tem como objetivos básicos proteger a diversidade biológica, disciplinar o processo de ocupação e assegurar a sustentabilidade do uso dos recursos naturais.

Art. 16. A Área de Relevante Interesse Ecológico é uma área em geral de pequena extensão, com pouca ou nenhuma ocupação humana, com características naturais extraordinárias ou que abriga exemplares raros da biota regional, e tem como objetivo manter os ecossistemas naturais de importância regional ou local e regular o uso admissível dessas áreas, de modo a compatibilizá-lo com os objetivos de conservação da natureza.

Art. 17. A Floresta Nacional é uma área com cobertura florestal de espécies predominantemente nativas e tem como objetivo básico o uso múltiplo sustentável dos recursos florestais e a pesquisa científica, com ênfase em métodos para exploração sustentável de florestas nativas.

Art. 18. AReserva Extrativista é uma área utilizada por populações extrativistas tradicionais, cuja subsistência baseia-se no extrativismo e, complementarmente, na agricultura de subsistência e na criação de animais de pequeno porte, e tem como objetivos básicos proteger os meios de vida e a cultura dessas populações, e assegurar o uso sustentável dos recursos naturais da unidade.

Art. 19. A Reserva de Fauna é uma área natural com populações animais de espécies nativas, terrestres ou aquáticas, residentes ou migratórias, adequadas para estudos técnicocientíficos sobre o manejo econômico sustentável de recursos faunísticos.

Art. 20. A Reserva de Desenvolvimento Sustentável é uma área natural que abriga populações tradicionais, cuja existência baseia-se em sistemas sustentáveis de exploração dos recursos naturais, desenvolvidos ao longo de gerações e adaptados às condições ecológicas locais e que desempenham um papel fundamental na proteção da natureza e na manutenção da diversidade biológica.

Art. 21. A Reserva Particular do Patrimônio Natural é uma área privada, gravada com perpetuidade, com o objetivo de conservar a diversidade biológica.

Assim, de acordo com os conceitos legais acima transcritos, é possível vislumbrar que as espécies de unidades de conservação possuem restrições e possibilidades diversas. Algumas possuem recursos naturais que devem ser totalmente preservados, sem qualquer tipo de intervenção humana. Outras possibilitam visitação, turismo e até mesmo moradia.

\section{Limites e circunstâncias da usucapião de imóveis em unidades de conservação}

Tendo visto, à vol d'oiseau, o que vem a ser a usucapião e as unidades de conservação, em todas as suas espécies, chega-se ao objetivo deste estudo, ou seja, a análise da possibilidade de existência de usucapião em áreas pertencentes a unidades de conservação.

Conforme já mencionado, as espécies de unidades são várias e cada uma com suas peculiares características, possibilidade de uso e restrições. Assim, uma conclusão pode ser desde já destacada, a de que não há regra geral sobre usucapião em área desta natureza, ou seja, que abranja todas as espécies de unidades.

Importante ressalvar neste ponto que a análise a ser ora empreendida perpassa pelo conflito entre dois direitos fundamentais, quais sejam: o direito à moradia e o direito ao meio ambiente ecologicamente equilibrado, ambos constitucionalmente previstos, de obrigatória harmonização, já que se encontram no mesmo nível hierárquico. Com propriedade, alerta Luís Roberto Barroso (2009, p. 374) que: 
Por força do princípio da unidade, inexiste hierarquia entre normas da Constituição, cabendo ao intérprete a busca da harmonização possível, in concreto, entre comandos que tutelam valores ou interesses que se contraponham. Conceitos como o de ponderação e concordância prática são instrumentos de preservação do princípio da unidade, também conhecido como princípio da unidade hierárquico-normativa da Constituição.

Assim, para a resolução deste conflito, é necessária a utilização da regra da ponderação. Segundo Robert Alexy (2011, p. 93), o conflito de normas constitucionais deve ser resolvido mediante um sopesamento entre os interesses conflitantes, definindo-se qual dos interesses (muitas vezes referentes a direitos fundamentais) tem o maior peso no caso concreto. Explicita o autor que:

Se dois princípios colidem - o que ocorre, por exemplo, quando algo é proibido de acordo
com um princípio e, de acordo com o outro, permitido -, um dos princípios terá que ceder.
Isso não significa, contudo, nem que o princípio cedente deva ser declarado inválido, nem
que nele deverá ser introduzida uma cláusula de exceção. Na verdade, o que ocorre é que
um dos princípios tem precedência em face do outro sob determinadas condições.

Dessa forma, o importante é equilibrar os dois direitos, não prevalecendo nem um nem outro de maneira irrestrita. Note-se que em determinadas situações o direito à moradia pode coexistir com a preservação do meio ambiente, quando exercido de acordo com o interesse coletivo. Mas ressalva Mila Malucelli Araujo (2008, p. 55) que:

... deve-se ter em mente, por um lado, a necessidade de preservação da natureza e, por outro, a relevância social do instituto da usucapião urbana (que confere a necessária segurança jurídica ao possuidor), a importância da concretização do direito à moradia (o qual representa uma necessidade vital do homem) e o papel positivo que a população pode ter na proteção dos recursos naturais.

Mesmo diante desta necessidade de ponderação, não se pode olvidar que se a legislação não admitir qualquer forma de habitação, por razões de fragilidade da região, inclusive ambiental, ou pela própria falta de segurança às ocupações no local, a usucapião não pode ser reconhecida. Destarte, diante do que foi até então exposto, cumpre decidir: qual é a ponderação a ser aqui realizada?

Com efeito, a solução mais razoável na hipótese é levar em consideração o que a própria lei prevê. Ou seja, se ela possibilitar a existência de particulares na unidade, a usucapião será permitida. Caso contrário, não. Assim, da leitura dos artigos acima transcritos, conclui-se que a possibilidade existe nas seguintes unidades: monumento natural, refúgio da vida silvestre, área de proteção ambiental, área de relevante interesse ecológico e reserva particular do patrimônio natural.

Nas demais espécies há previsão expressa na lei de que as terras particulares dentro de seu domínio, após criação, serão desapropriadas. Tal determinação parte do pressuposto de que são áreas mais frágeis, ambientalmente falando, e que devem ser protegidas de forma mais radical. Por esta razão, não havendo a possibilidade de manutenção de particulares dentro da unidade, a usucapião está também vedada, privilegiando-se, neste caso, o direito ao meio ambiente ecologicamente equilibrado. 


\section{Usucapião em áreas de preservação permanente}

Por sua vez, as áreas de preservação permanente constituem-se em espaços territoriais especialmente protegidos, de acordo com o disposto no inciso III, $\S 1^{\circ}$, do art. 225 da Constituição Federal. O detalhamento destas áreas encontra-se no Código Florestal, que assim as define:

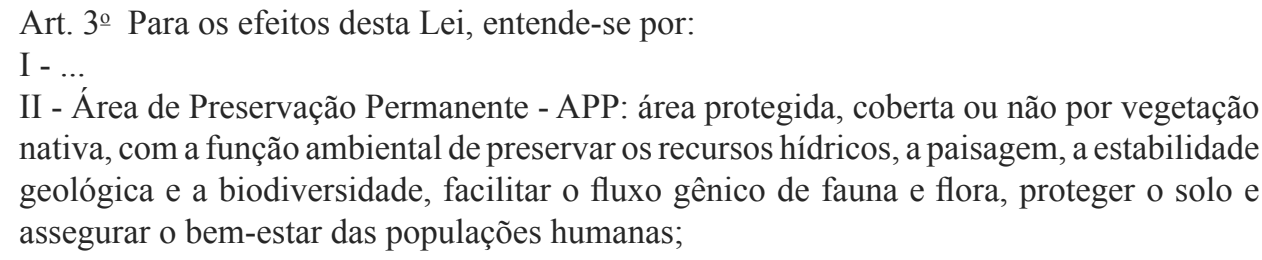
nativa, com a função ambiental de preservar os recursos hídricos, a paisagem, a estabilidade geológica e a biodiversidade, facilitar o fluxo gênico de fauna e flora, proteger o solo e assegurar o bem-estar das populações humanas;

$\mathrm{O}$ art. $4^{\circ}$ do mencionado Código declara as hipóteses em que uma área deve ser considerada de preservação permanente. Começa com as faixas marginais aos cursos d'água e termina com as veredas, adicionando no art. $6^{\circ}$ outras áreas, como as restingas, desde que assim declaradas por ato do chefe do Poder Executivo. ${ }^{5}$ Basicamente, as APP's são áreas nas quais a vegetação, devido à sua relevância, deve ser mantida intacta, garantindo a preservação dos recursos hídricos, estabilidade geológica e biodiversidade, além do bem-estar das populações. Por esta razão, elas possuem um regime de proteção bastante rígido, sendo a regra a intocabilidade. A supressão da vegetação é permitida no Código Florestal, apenas em casos de utilidade pública, interesse social ou baixo impacto ambiental.

Note-se que as áreas de preservação permanente foram criadas para proteger o ambiente natural, não se tratando de áreas adaptadas para alterações ou uso da terra, havendo necessidade de estarem cobertas pela vegetação original. A relevância destas vegetações é que irão atenuar a erosão do solo, regularização dos fluxos hídricos, redução do assoreamento dos cursos de água, etc.

Ocorre que, não raramente, áreas de preservação permanente são ocupadas por população de baixa renda, que não dispõe de meios para adquirir moradia na área urbana nas médias e grandes cidades, para onde se mudam à procura de emprego. Disto surgem situações especiais, às quais o Direito não vem dando solução.

Diante dessas circunstâncias, o Direito acaba por criar tantos conflitos quanto os que se
propõe a resolver. Como certos imóveis, diante de sua localização privilegiada, segurança
e opções de lazer, por exemplo, são de aquisição restrita e seletiva, de modo a dificultar
o acesso à terra por parte das classes menos favorecidas economicamente, estas são
compelidas a viver em regiões afastadas dos núcleos urbanos, muitas vezes inóspitas,
onde a habitação não é permitida ou é restringida pelas leis. (ARAUJO, 2008, p. 53)

Vejamos um exemplo. Em Curitiba, PR, foram propostas diversas ações de usucapião especial, ou seja, de áreas inferiores a $250 \mathrm{~m}^{2}$, nas quais o prazo de posse é de apenas 5 (cinco) anos, por pessoas que afirmavam manter a posse mansa e pacífica de áreas de preservação permanente, mananciais próximos de rios que abastecem a população local. As ações foram julgadas improcedentes pelo Tribunal de Justiça do Estado do Paraná, porque a posse não atendia à função socioambiental. Confira-se: 
proteção pelo poder público decorrente da constituição federal. Limitação municipal à ocupação do solo que determina uma unidade familiar a cada $10.000 \mathrm{~m} 2$. Posse que não atende à função sócio-ambiental. Impossibilidade de declaração de domínio. Pretensão improcedente. Sentença reformada. Recurso provido. (TJPR, Processo 816707/11/2012 21-7)

No mesmo sentido decidiu a Corte Estadual em outros recursos em ações de usucapião (TJPR, Processo 947227-9; TJPR, Processo 866952-7). Decidindo recurso o envolvendo ordem de desocupação de tal tipo de área protegida, manteve o Tribunal de Justiça a liminar de primeira instância, apenas aumentando o prazo para 6 (seis) meses. Confira-se:

PROCESSO CIVIL - AGRAVO DE INSTRUMENTO - AÇÃO CIVIL PÚBLICA AMBIENTAL - Insurgência recursal contra decisão que deferiu liminar, determinando a desocupação de área de preservação ambiental e embargo de obras no local - viabilidade em razão da indisponibilidade e indivisibilidade do direito ao meio ambiente ecologicamente equilibrado - área de proteção ambiental do Iraí - princípio da prevenção e precaução prazo de 60 (sessenta) dias para desocupação e reassentamento das famílias - não razoável - dilação de prazo para 6 (seis) meses - recurso conhecido e parcialmente provido. (TJPR, Processo 951687-4)

Assim, a ocupação de APPs por pessoas de baixa renda, geralmente sem outro local para morar, revela-se um problema mais de natureza social do que jurídica. Mas, se regra geral a usucapião é inviável, há hipóteses em que ela pode ser reconhecida. Veja-se o que prevê o art. $7^{\circ}$ do Código Florestal:

Art. 7o A vegetação situada em Área de Preservação Permanente deverá ser mantida pelo proprietário da área, possuidor ou ocupante a qualquer título, pessoa física ou jurídica, de direito público ou privado.

Portanto, existe a possibilidade de propriedade particular e também de exercício de posse destas áreas, muito embora elas devam ser preservadas. Logo, é possível ter reconhecida a legitimidade da pretensão de habitantes que lá se estabeleceram durante o tempo necessário para usucapir. Mas essa permanência e a consequente usucapião não podem ser reconhecidas se trouxerem riscos às suas vidas, por exemplo, em encostas de morro ou em zonas alagadiças. Por outro lado, o reconhecimento da usucapião não significa, obviamente, que o novo proprietário possa utilizar a APP contrariando normas ambientais.

\section{Conclusões}

a. A usucapião é forma de aquisição da propriedade pela posse continuada, desde que observados determinados requisitos previstos no ordenamento jurídico. Ela fundamenta-se, principalmente, na função social da propriedade, considerada como princípio em nossa atual Constituição Federal.

b. As unidades de conservação, previstas na Lei 9.9985, de 2000, e as áreas de preservação permanente, previstas no Código Florestal, constituem-se em espaços diferentes, todos sob o manto da proteção integral, alguns de forma absoluta, outros com possibilidade de uso sustentável. 
c. Nas áreas ambientalmente protegidas em que se admite a usucapião, por exemplo, aquela que tenha uma nascente (Código Florestal, art. $4^{\circ}$, inc.IV), o pedido é juridicamente possível, contudo a parte do imóvel que circunda a nascente deverá ser preservada.

d. No atual Código de Processo Civil, não há um procedimento especial para o pedido de usucapião, a qual deverá processar-se pelo rito ordinário, com todas as cautelas da legislação revogada, inclusive vista ao Ministério Público. Não há vedação legal para que o pedido envolvendo moradias populares se processe no Cartório de Registro de Imóveis. Todavia, pela complexidade de que, normalmente, se revestem tais requerimentos, a via judicial será mais adequada.

e. Os conflitos entre o direito à moradia e à preservação do meio ambiente, ambos de hierarquia constitucional, devem ser decididos com foco no caso concreto, prevalecendo o interesse de maior peso, se ambos não puderem coexistir.

\section{Notas}

1 É licenciado em Direito pela Faculdade Católica de Direito de Santos (1968), mestre e doutor em Direito pela Universidade Federal do Paraná (1989 e 1999) e pós-doutor pela Universidade de São Paulo (USP), na área de Saúde Pública. Foi Promotor de Justiça nos Estados do PR e SP (10 anos) e Juiz Federal (26 anos), tendo exercido a presidência do Tribunal Regional Federal da 4a. Região . Aposentado do cargo de Desembargador Federal em 2006, atualmente é professor de Direito Ambiental da graduação e da pós-graduação da Pontifícia Universidade Católica do Paraná, membro do Grupo de Especialistas em Judiciário da International Union For Conservation Of Nature, conferecista internacional na área do Direito Ambiental e em Política Judiciária e Administração da Justiça, sendo fundador do Instituto Brasileiro de Administração do Sistema Judicial - IBRAJUS e Presidente da "International Association for Courts Administration - IACA", com sede em Louisville, Kentucky, Estados Unidos da América. Membro da "Associação de Professores de Direito Ambiental - APRODAB", com sede em São Paulo, Brasil, e da "Asociacion Internacional de professores de Derecho Ambiental", sede em Lima, Peru. Doutor "Honoris Causa em Humanidades", outorgado pela Universidad Paulo Freire, Manágua, Nicarágua. Membro do Instituto dos Advogados Brasileiros. Dados complementares no sítio: www.vladimirfreitas.com.br. E-mail: vladimir. freitas@terra.com.br

2 Mestranda no Programa de Pós-Graduação em Direito Ambiental Internacional da Universidade Católica de Santos (Unisantos), possui bacharelado em Direito (2007 - 2011) pela Universidade Estácio de Sá - SP. É advogada atuante nas áreas ambiental e empresarial, Professora Universitária e Coordenadora da Coordenadoria de Advocacia Extrajudicial e Métodos Alternativos de Solução de Conflitos da Comissão do Acadêmico de Direito da OAB/SP Seccional e da Subcomissão de Águas e Unidades de Conservação da $\mathrm{OAB} / \mathrm{SP}$, Subseção de Santo Amaro. Atuou na Secretaria Municipal de Promoção da Igualdade Racial da Cidade de São Paulo, na gestão dos Conselhos de Comunidades Tradicionais Religiosas. E-mail: amorim. jur@gmail.com

3 Mestre e Doutora em Direito Socioambiental pela PUCPR. Oficial de Gabinete da Vara Federal Ambiental e Agrária (13 a .) de Curitiba, PR. Autora dos livros: Zona costeira e meio ambiente - aspectos jurídicos e Tratados internacionais de Direito Ambiental, pela Juruá Editora, além de diversos artigos na mesma área. E-mail: maripassosdefreitas@gmail.com

4 Art. 216-A. Sem prejuízo da via jurisdicional, é admitido o pedido de reconhecimento extrajudicial de usucapião, que será processado diretamente perante o cartório do registro de imóveis da comarca em que estiver situado o imóvel usucapiendo, a requerimento do interessado, representado por advogado, instruído com: 
I - ata notarial lavrada pelo tabelião, atestando o tempo de posse do requerente e seus antecessores, conforme o caso e suas circunstâncias;

II - planta e memorial descritivo assinado por profissional legalmente habilitado, com prova de anotação de responsabilidade técnica no respectivo conselho de fiscalização profissional, e pelos titulares de direitos reais e de outros direitos registrados ou averbados na matrícula do imóvel usucapiendo e na matrícula dos imóveis confinantes;

III - certidões negativas dos distribuidores da comarca da situação do imóvel e do domicílio do requerente; IV - justo título ou quaisquer outros documentos que demonstrem a origem, a continuidade, a natureza e o tempo da posse, tais como o pagamento dos impostos e das taxas que incidirem sobre o imóvel.

$\S 1^{\circ} \mathrm{O}$ pedido será autuado pelo registrador, prorrogando-se o prazo da prenotação até o acolhimento ou a rejeição do pedido.

$\S 2$ o Se a planta não contiver a assinatura de qualquer um dos titulares de direitos reais e de outros direitos registrados ou averbados na matrícula do imóvel usucapiendo e na matrícula dos imóveis confinantes, esse será notificado pelo registrador competente, pessoalmente ou pelo correio com aviso de recebimento, para manifestar seu consentimento expresso em 15 (quinze) dias, interpretado o seu silêncio como discordância. § 3ํㅡ oficial de registro de imóveis dará ciência à União, ao Estado, ao Distrito Federal e ao Município, pessoalmente, por intermédio do oficial de registro de títulos e documentos, ou pelo correio com aviso de recebimento, para que se manifestem, em 15 (quinze) dias, sobre o pedido.

$\S 4^{\circ} \mathrm{O}$ oficial de registro de imóveis promoverá a publicação de edital em jornal de grande circulação, onde houver, para a ciência de terceiros eventualmente interessados, que poderão se manifestar em 15 (quinze) dias.

§ 5o Para a elucidação de qualquer ponto de dúvida, poderão ser solicitadas ou realizadas diligências pelo oficial de registro de imóveis.

$\S 6^{-}$Transcorrido o prazo de que trata o $\S 4^{\circ}$ deste artigo, sem pendência de diligências na forma do $\S$ 5o deste artigo e achando-se em ordem a documentação, com inclusão da concordância expressa dos titulares de direitos reais e de outros direitos registrados ou averbados na matrícula do imóvel usucapiendo e na matrícula dos imóveis confinantes, o oficial de registro de imóveis registrará a aquisição do imóvel com as descrições apresentadas, sendo permitida a abertura de matrícula, se for o caso.

$\S 7$ Em qualquer caso, é lícito ao interessado suscitar o procedimento de dúvida, nos termos desta Lei.

$\S 8^{\circ}$ Ao final das diligências, se a documentação não estiver em ordem, o oficial de registro de imóveis rejeitará o pedido.

§ 9ำ A rejeição do pedido extrajudicial não impede o ajuizamento de ação de usucapião.

$\S 10$. Em caso de impugnação do pedido de reconhecimento extrajudicial de usucapião, apresentada por qualquer um dos titulares de direito reais e de outros direitos registrados ou averbados na matrícula do imóvel usucapiendo e na matrícula dos imóveis confinantes, por algum dos entes públicos ou por algum terceiro interessado, o oficial de registro de imóveis remeterá os autos ao juízo competente da comarca da situação do imóvel, cabendo ao requerente emendar a petição inicial para adequá-la ao procedimento comum.

5 Art. 4o Considera-se Área de Preservação Permanente, em zonas rurais ou urbanas, para os efeitos desta Lei:

I - as faixas marginais de qualquer curso d'água natural perene e intermitente, excluídos os efêmeros, desde a borda da calha do leito regular, em largura mínima de:

a) 30 (trinta) metros, para os cursos d'água de menos de 10 (dez) metros de largura;

b) 50 (cinquenta) metros, para os cursos d'água que tenham de 10 (dez) a 50 (cinquenta) metros de largura; 
c) 100 (cem) metros, para os cursos d'água que tenham de 50 (cinquenta) a 200 (duzentos) metros de largura; d) 200 (duzentos) metros, para os cursos d'água que tenham de 200 (duzentos) a 600 (seiscentos) metros de largura;

e) 500 (quinhentos) metros, para os cursos d'água que tenham largura superior a 600 (seiscentos) metros;

II - as áreas no entorno dos lagos e lagoas naturais, em faixa com largura mínima de:

a) 100 (cem) metros, em zonas rurais, exceto para o corpo d'água com até 20 (vinte) hectares de superfície, cuja faixa marginal será de 50 (cinquenta) metros;

b) 30 (trinta) metros, em zonas urbanas;

III - as áreas no entorno dos reservatórios d'água artificiais, decorrentes de barramento ou represamento de cursos d'água naturais, na faixa definida na licença ambiental do empreendimento;

IV - as áreas no entorno das nascentes e dos olhos d'água perenes, qualquer que seja sua situação topográfica, no raio mínimo de 50 (cinquenta) metros;

$\mathrm{V}$ - as encostas ou partes destas com declividade superior a $45^{\circ}$, equivalente a $100 \%$ (cem por cento) na linha de maior declive;

VI - as restingas, como fixadoras de dunas ou estabilizadoras de mangues;

VII - os manguezais, em toda a sua extensão;

VIII - as bordas dos tabuleiros ou chapadas, até a linha de ruptura do relevo, em faixa nunca inferior a 100 (cem) metros em projeções horizontais;

IX - no topo de morros, montes, montanhas e serras, com altura mínima de 100 (cem) metros e inclinação média maior que $25^{\circ}$, as áreas delimitadas a partir da curva de nível correspondente a $2 / 3$ (dois terços) da altura mínima da elevação sempre em relação à base, sendo esta definida pelo plano horizontal determinado por planície ou espelho d'água adjacente ou, nos relevos ondulados, pela cota do ponto de sela mais próximo da elevação;

$\mathrm{X}$ - as áreas em altitude superior a 1.800 (mil e oitocentos) metros, qualquer que seja a vegetação;

XI - em veredas, a faixa marginal, em projeção horizontal, com largura mínima de 50 (cinquenta) metros, a partir do espaço permanentemente brejoso e encharcado.

Art. $6^{\circ}$ Consideram-se, ainda, de preservação permanente, quando declaradas de interesse social por ato do Chefe do Poder Executivo, as áreas cobertas com florestas ou outras formas de vegetação destinadas a uma ou mais das seguintes finalidades:

I - conter a erosão do solo e mitigar riscos de enchentes e deslizamentos de terra e de rocha;

II - proteger as restingas ou veredas;

III - proteger várzeas;

IV - abrigar exemplares da fauna ou da flora ameaçados de extinção;

$\mathrm{V}$ - proteger sítios de excepcional beleza ou de valor científico, cultural ou histórico;

VI - formar faixas de proteção ao longo de rodovias e ferrovias;

VII - assegurar condições de bem-estar público;

VIII - auxiliar a defesa do território nacional, a critério das autoridades militares.

IX - proteger áreas úmidas, especialmente as de importância internacional. 


\section{Referências}

ALEXY, Robert. Teoria dos direitos fundamentais. 2 ed. São Paulo: Malheiros, 2011.

ARAUJO, Mila Malucelli. Usucapião urbana em áreas de mananciais: ponderação entre o direito fundamental à moradia e o direito fundamental ao meio ambiente. Curitiba: 2008, UFPR. Monografia de final de curso de Direito, Disponível em: http://acervodigital.ufpr.br/bitstream/handle/1884/31013/M\%20 1094.pdf? sequence=1. Acesso em: 15 out. 2016.

AYALA, Patryck de Araújo. In: CANOTILHO, José Joaquim Gomes; LEITE, José Rubens Morato (organizadores). Direito constitucional ambiental brasileiro. São Paulo: Saraiva, 2007.

BARROSO, Luís Roberto. Interpretação e aplicação da Constituição. São Paulo: Saraiva, 2009.

BULOS, Uadi Lammêgo. Constituição Federal anotada. 9 ed. Revista e atualizada até a EC n. 57/2008. p. 28-29. São Paulo: Saraiva, 2009.

FIORILlO, Celso Antonio Pacheco. Curso de Direito Ambiental Brasileiro. 12. ed. São Paulo: Saraiva, 2011.

FREITAS, Vladimir Passos de. Cachoeiras, exploração econômica e proteção do meio ambiente. In: Veredas do Direito (Belo Horizonte), v. 12, 2015.

FIUZA, Cesar. Procedimentos para ação de usucapião ficam claros no novo CPC. 2015. Disponível em: http://www.conjur.com.br/2015-ago-17/direito-civil-atual-procedimentos-acao-usucapiao-fica-claro-cpc. Acesso em: 05 out. 2016.

GOMES, Orlando. Direitos Reais. 20 ed. Rio de Janeiro: Editora Forense, 2010.

MACHADO, Paulo Affonso Leme. Direito Ambiental Brasileiro. 17. ed. São Paulo: Malheiros, 2009.

MACIEL, Amanda Amorim. Tutela Jurídica da Unidade de Conservação APA Bororé-Colônia em Face do Direito Ambiental Brasileiro. 2011. Disponível em http://amorimjur.jusbrasil.com.br/artigos/114440002/tutela-juridica-da-unidade-de-conservacao-apa-borore-colonia-em-face-do-direito-ambiental-brasileiro. Acesso em: 22 abr. 2016.

PADILHA, Norma Sueli. Fundamentos Constitucionais do Direito Ambiental. Rio de Janeiro: Elsevier, 2010.

RODRIGUES, José Eduardo Ramos. Sistema nacional de unidades de conservação. São Paulo: Editora Revista dos Tribunais, 2005.

SILVA, José Afonso da. Direito Ambiental Constitucional. 5. ed. São Paulo: Editora Malheiros, 2004.

Direito Ambiental Constitucional. 9. ed. São Paulo: Editora Malheiros, 2011.

SIRVINSKAS, Luís Paulo. Manual de Direito Ambiental. 10. ed. São Paulo: Saraiva, 2012.

TJPR, Processo 816707/11/2012 21-7, 17ª . Câmara Cível, relator Vicente Misurelli, julgado em 07/11/2012.

TJPR, Processo 947227-9, 17ª . Câmara Cível, relator Helton Jorge, julgado em 08.05.2013 e Processo 866952-7, $18^{\mathrm{a}}$. Câmara Cível, relator Marcelo Dalla Dea , julgado em 07.11.2012.

TJPR, Processo 951687-4, 4⿳. Câmara Cível, relator Wellington Moura, julgado em 09.04.2013.

VENOSA, Sílvio de Sálvio. Teoria Geral do Direito Civil. 3. ed. São Paulo: Saraiva, 2003. 